\title{
Michael Crummey's River Thieves in the light of rescue history
}

\begin{abstract}
Born and raised in Newfoundland and Labrador, Michael Crummey uses his inside knowledge to describe the region's peculiarities in vivid detail. All four of his novels are set in Newfoundland and weave a story of its inhabitants throughout different moments in the island's history. Though Crummey's prose is broadly characterized as historical fiction, his novels differ from their traditional counterparts. This article aims to invite a reading of Crummey's works through the prism of rescue history, a concept recently introduced by a Polish scholar, Ewa Domańska. Rescue history, drawing on frontier and post-colonial studies among others, is preoccupied with local, potential, existential and affirmative history whose goal is to rescue the future. Although the concept of rescue history encompasses a variety of disciplines and activities, this article will focus on the literary realization of the notion of rescue history in Crummey's debut novel River Thieves, published in 2002. Based on historical accounts of Captain David Buchan's expedition to Red Indian Lake, whose aim was to encourage trade and put an end to hostilities between English settlers and Beothuks, the novel encourages a compassionate revisiting of the chronicled events. Weaving an intricate web of human relations and dependencies, Crummey manages to restore agency to those who are situated on the periphery either due to gender, status or origin, thus reminding the reader that we are all capable of changing the course of history.
\end{abstract}

Keywords: rescue history, affirmative history, Beothuks, Demasduit, First Nations.

Born and raised in Newfoundland and Labrador, Michael Crummey celebrates the region's distinctness. All his novels are set in Newfoundland and weave stories of its inhabitants throughout different moments in the island's history. Spinning narratives that hark back to the beginning of the nineteenth century as well as encompass present-day events, Crummey shows Newfoundland's transformation from British colony to Canadian province. Though more than six decades have passed since Newfoundland's union with Canada, the vast majority of the island's inhabitants have retained their distinct sense of identity and declare themselves first as Newfoundlanders, then as Canadians. The sense of belonging primarily to the land rather than a country permeates the writer's oeuvre.

Crummey's characters seem to be deeply rooted in their locality, which is also mirrored in their language. Recurrent inscriptions from the Dictionary of Newfoundland English manifest that the local variety of English developed a plethora of idiomatic phrases unknown to other native speak- 
ers of English. An old hag to mean "a nightmare," to have the face of a robber's horse denoting "a brazen attitude," or $d$ wall, signifying "a state between sleeping and waking," are only a few examples of linguistic distinctions between Canadians and Newfoundlanders. Though central to heroes' lives, Newfoundland is, nevertheless, situated on the Canadian periphery. Therefore, there are a number of literary approaches that may be applied in analyzing and interpreting Crummey's novels, such as regional studies, border studies, postcolonial studies or ecocriticism, to mention but a few.

The aim of this article, however, is to invite a reading of Crummey's debut novel, River Thieves, through the prism of rescue history, a concept developed by a Polish scholar, Ewa Domańska, which is an amalgam of different, already existing methodologies. The project of rescue history is a conglomerate of seemingly diverse theories such as the theory and history of historiography, ecocide and genocide studies, posthumanities or ecological humanities. Drawing upon each of them, rescue history aims to achieve its main goal, that is to rescue the future. Methodologically, rescue history is preoccupied with local, potential, existential, ecological and affirmative history (Domańska, 26) that may aid to build a better future for both human and non-human inhabitants of our planet.

Based on historical accounts of Captain David Buchan's expedition to Red Indian Lake, whose aim was to encourage trade and put an end to hostilities between English settlers and Beothuks, the novel encourages a compassionate revisiting of the chronicled events. In one of the interviews for the Calgary Herald, Crummey acknowledges his obsession with history in the following terms:

One of my obsessions as a writer is how does where we come from make us who we are... How does our past shape our present. There are some readers out there who say things like 'Why are you obsessed with what is happening the past [sic], why don't you write about what is happening today?' For me, I feel like you cannot write about what is happening today without writing about what has happened in the past. Those things are inseparable. Somehow that has become how I write. Those scenes start in the present and without any break they move into the past and then back to the present and sometimes there are three or four different levels within a single scene. I feel that is absolutely true of how we are in the world. (Crummey 2014)

Three elements of Crummey's confession that deserve special attention and that will be further analyzed are as follows: the belief that now is the continuity of the past, the multi-dimensional aspect of some of the scenes in the novel that reconfigure depending on the focalizer, and the notion of "being in the world," which draws significantly on ecocriticism and geopoetics.

The first element, that is, the belief that now is the continuity of the past, is demonstrated through intergenerational transmission. Encountering the ancestors of important or historical figures offers a metaphorical handshake across time; it becomes the meeting point between the present and the past. Apparently, the memory of the events that constitute the subject matter of the discussed novel is still a strong presence in the life of Newfoundlanders. 
When I wrote River Thieves, which is about events that took place two hundred years ago, but it concerns a particular family, the Peytons, I could not believe how many Peytons I ran into after that book came out. I got to meet a Mr. Edgar Bear. He was 93, and his grandmother knew John Peyton Jr. So I was sitting next to this man, if I held his hand, he held his grandmother's hand, she was holding John Peyton Jr.'s hand. And that was an amazing moment--just to see how close all of that is to the present still. That is not something that doesn't exist anymore, it's very present to people in Newfoundland. (Crummey 2012)

Crummey's observation that the past and the present are inseparable, however, resonates with rescue history, yet in a different respect, namely, that through studying the past we can rescue the future. The modern world is built upon past victories to the same extent that it is shaped by past failures, wrong choices and missed opportunities. Consequently, the shape of the future depends on the present moment and decisions yet to be made, of which the pivotal concern is the acknowledgment of other narratives excluded from the official history. Rescue history encourages researchers to unearth those elements from history that have been suppressed, ignored, forbidden or misrepresented in official narratives (Domańska, 13), with a special focus placed on locality. In this sense, it rests upon Foucault's concept of counterhistory.

In Roman-style history, the function of memory was essentially to ensure that nothing was forgottenor in other words, to preserve the law and perpetually to enhance the luster of power for so long as it endured. The new history that now emerges, in contrast, has to disinter something that has been hidden, and which has been hidden not only because it has been neglected, but because it has been carefully, deliberately, and wickedly misrepresented. Basically, what the new history is trying to show is that power, the mighty, the kings, and the laws have concealed the fact that they were born of the contingency and injustice of battles. (Foucault, 72)

The extinction of Red Indians as a result of settlers' expansion in Newfoundland is undeniably one of the most ignominious events in the island's history, which, unsurprisingly, has come to function as a source of national trauma but, peculiarly, also laid a foundation stone for the emergence of the national identity of Newfoundlanders. Cynthia Sugars explicates it in the following terms,

The extermination of the Beothuk Indians in Newfoundland has for a long time figured as a kind of formative event in Newfoundland and Canadian culture, a foundational trauma contributing to a constitutive and irreversible absence in official versions of invader-settler history. In effect, the Beothuk trauma, as experienced by the Beothuk themselves, is appropriated as a national trauma, or, should I say, Canadian nationalist discourse represents this tragedy as though it were a transferable trauma in order to conjure the event as a constitutive beginning for national self-definition. (150)

Therefore, writing about the lost tribe of Red Indians without appropriating their trauma is a nearly impossible task for someone who is a descendant of British settlers. Yet, Michael Crummey 
seems to have successfully avoided the trap of presenting the Beothuk as the object of "both Canadian postcolonial guilt (over past atrocities) and postcolonial desire (for origins/authenticity)" (Sugars, 152). The aim of River Thieves is not to revindicate but to express the notion of loss as well as offer a deeper understanding of the circumstances that led to the dramatic events described in the novel and the ultimate extinction of the Beothuk tribe.

As the first settlers searched for places convenient for fishing and hunting they subsequently drove the Red Indians ${ }^{6}$ inland towards Red Indian Lake. Though such an arrangement seemed initially to serve as a basis for a peaceful side-by-side existence with the incidents of friendly exchange of goods, it soon converted into a bloody war over the territory and animals between the Red Indians and some of the most affluent settlers that lived off fishing and hunting. Through the introduction of a wide array of characters, Crummey manages to portray settlers as a heterogeneous group, composed of individuals that differ in their viewpoints, attitudes, values, and conduct, the case of the Peytons being the most vivid example. Peyton Senior has a reputation for being a hardened enemy of Red Indians and has allegedly killed one with the use of a trap-bed. Peyton Junior, on the other hand, embraces governor Duckworth's mission to "protect the Indians" and "to establish a formal relationship" (Crummey 2003, 20). Unlike his father, young Peyton sees a possibility of peaceful co-existence between settlers and the Red Indians.

Making Peyton Junior a main focalizer in River Thieves, Crummey shifts the focal point from conflicts and bloodshed to cooperation, coexistence, neighbourhood, or friendship. By accommodating Mary, the captured Beothuk woman, at his house and treating her like a guest with the utmost respect, Peyton Junior sets a new paradigm for relations between settlers and indigenous people. The relationship that young Peyton forges with the native woman balances or perhaps even redeems the haunting recollection he has of a captive little Indian girl exhibited to the public for a penny by one of his father's old friends. Needless to say, though Mary is a respected guest at Peytons' house, she also remains a captive that is expected to act as an intermediary between her people and settlers once she learns to speak English. However, the fact that emphasizes the shift towards peaceful coexistence between the two hostile groups is that Mary is no longer seen as a savage or exotic Other but a prospective partner in mediation. The potentiality of friendly coexistence between settlers and First Nations is additionally strengthened by a marital union between Reilly and his Mi'kmaq wife, Annie Boss. In this respect, River Thieves shows "the originary moment when what could have been was separated from what is" (Chafe, 93).

Mary never fully learns English (whether by will or not is unclear). She speaks in a "relentlessly present tense" (305), and will be remembered as always already perched at the moment of extinction. This fact, more than others, will come to haunt her captors. Mary, and the Beothuk more generally, embody

6 In the following article the name Red Indians is used interchangeably with the Beothuks to denote a particular tribe of First Nations of Newfoundland. The English name of the tribe derives from the Beothuk tradition of covering their bodies with the red ochre and is in no way a derogatory term. 
this in-between moment, when going back was impossible and going forward, as before, was equally impossible. In this way, the Beothuk represent the end of an era, for Beothuk and settlers both. A nostalgia for originary nostalgia. A perpetual penultimate. (Sugars, 161)

River Thieves is like a piece of amber in which Demasduit, the Beothuk name of Mary, is preserved for prosperity; a silent witness, revealing nothing of her own people but testifying to their eradication. Though her capture constitutes the backbone of the novel, Mary is in no way a central character in the story. To make her the protagonist, Crummey would be forced to step into her shoes, which would lead to the re-appropriation of Mary's story and her subsequent re-colonization against which bell hooks warns in the following terms:

Often this speech about the "Other" annihilates, erases: "No need to hear your voice when I can talk about you better than you can speak about yourself. No need to hear your voice. Only tell me about your pain. I want to know your story. And then I will tell it back to you in a new way. Tell it back to you in such a way that has become mine, my own. Re-writing you, I rewrite myself anew. I am still author, authority. I am still the colonizer, the speaking subject, and you are now at the center of my talk." (151-152)

Although the presence of Mary as well as her people is crucial to the story, Crummey manages to avoid the pitfalls bell hooks described. Narrating the events from the perspective of the settlers, Peyton Senior, his adult son and their housemaid Cassie Jure, not only does the author avoid a secondary colonization of the Beothuk, but he also calls the objectivity of the narrative into question. The understanding and the inevitable interpretation of the events in the novel differ greatly between the three aforementioned characters. As the plot unwinds, it becomes evident that what the characters see may be deceptive, for one's vision of the world is always enmeshed in one's subjective life experience and presuppositions. The fallibility of the narrative, and history in a broader understanding, is additionally reinforced by the fact that, as Chafe observes, from the moment of the capture of Mary at Red Indian Lake "the novel reads like an investigation (Crummey actually lifts excerpts from official letters and inquiries), and the only certainty seems to be that no one is as he or she seems" (104).

Rescue history is also understood as existential history that contemplates the meanders of the human condition. It is a story about people who are full of contradictions and who live in the grey zones of everyday dilemmas, both cognitive and moral ones (Domańska, 18). The characters of River Thieves are full-bloodied people, fraught with vices but also possessing redeeming qualities. Entangled in their often traumatic past, they all strive for a better future in Newfoundland, though in different ways and at different costs. One of the least likable characters, Peyton Senior, is a tough, unemotional man that seems to care about nothing but his son and estate. Yet, he is the one to rescue an Irish ex-convict, Reilly, as well as Cassie. Both these seemingly inadvertent decisions, which stemmed more from Peyton's moral judgment than mercy, will affect his and their lives irrevocably. Having Reilly kill one of the Red Indians in order to save old Peyton's life 
during the second expedition to Red Indian Lake, Crummey highlights the intricacy of interhuman relations and restores agency to each of the characters. Little did Peyton Senior suspect that by offering to remove the T-shaped iron brand off the hand of an underage Irish thief and providing him with a job at his estate would he in fact rescue his own life in the long run. As Domańska observes, at the centre of rescue history, "there is a realistic and carnal subject-agent, acting in certain socio-political surroundings, belonging to a certain community, whose view of the world and of the past are conditioned by various locations" (19). ${ }^{7}$ Ironically, the illusorily peripheral characters and events in the novel become central in its grand finale. The illicit love affair between Cassie and Captain Buchan, accidentally discovered by Peyton Junior, saves Reilly from the gallows. The prospects of shame that would come with the public discovery of the captain's adultery prevent him from revealing the actual circumstances of the death of two Red Indians during the second expedition in the official report, thus acquitting its members of the killings.

Alongside empowering individual characters regardless of their peripheral locality, rescue history looks for "innovative forms of agency" that encompass non-human elements such as animals, plants, objects or even sounds and light. In this respect, it transcends the Anthropocene and points to nature in its own right (Domańska, 20). Nature features prominently in River Thieves, as in every Crummey novel, for life on this island is closely intertwined with its climate and animal resources. Though generous and picturesque in summer months, in winters the Newfoundland of River Thieves turns into a hostile land where some paths are impenetrable and the harsh climate kills inhabitants due to cold-induced diseases, starvation or injuries incurred during fishing or hunting expeditions. In the winter of 1817, the governor of Newfoundland dies of bronchial congestion that resulted from "the constant damp and cold of the governor's residence" (Crummey, 158). The severity of this winter is demonstrated in the following passage from the novel:

The constant frost of that year had sealed the coast in a solid band of ice from the early days of December. In order to return the governor's body to England, Buchan pressed three hundred shoremen into service beside crewmen from the Drake, Egeria and the Fly to carve a passage clear of the harbour.... Three weeks after the work began, the HMS Fly left St. John's with the earthly remains of Governor Pickmore preserved in a large puncheon of rum. ... Within a week the relentlessly cold weather had closed it over again and the harbour remained inaccessible to shipping until May. (Crummey, 158-9)

Similarly, both expeditions to Red Indian Lake that take place in the winters of 1811 and 1818 demonstrate how human history is closely entangled in or becomes natural history. The men struggle with the elements and the unbridled river that almost claims the life of one of the soldiers, as well as hunt down animals to ensure their provisions are sufficient and do not run out prematurely. Their lives depend on nature that, in turn, becomes an agent in their history.

7 Author's own translation from Polish. 
On principle, rescue history questions the notion of human exceptionalism, as well as the instrumental treatment of nature as a resource to satisfy human needs, drawing upon ecological and environmental studies. It calls for "a heightened sensitivity towards the environment in which we try to live" (White, 165). Nearly all characters in the novel kill various animals for food without getting squeamish, for their survival relies on animal flesh. Yet, River Thieves features one scene of seal slaughter for pelts that most readers will probably find abhorrent. This scene, which involves ripping still warm nearly beating hearts out of seals' chests to satisfy hunger after the hard toil of slaughter, demonstrates a clear transgression (Crummey, 71). It is not the act of eating a raw seal heart that makes the scene savage but the manner in which it is done, which is totally devoid of any empathy.

He [old Peyton] used the heel of the boot to crack the exposed breastbone and then opened the chest cavity to cut the large fist of its heart free. He held it in his hand, the organ still hot to the touch, and he brought it to his mouth, biting into it as he would an apple. He offered it to Cassie and then to Peyton, and they ate the raw flesh together, licking the blood from their lips. (Crummey, 71)

The violent and haughty behaviour of old Peyton stands in stark contrast with young Peyton's empathetic observation first of the seal's "dark delicate nostrils testing the air" (70), and then the painful recollection of "stripped carcasses on ice, inert, emptied of the energy of the animate" (71). Peyton Junior's sympathy for other people as well as other creatures, and his resistance to violence, unfortunately make him a laughingstock among his father's friends and workers. Nonetheless, it is Peyton Junior that is nominated a new justice of the peace, setting a new paradigm for a more empathetic administrative face.

Last but not the least, rescue history emphasizes different forms of witnessing and giving testimony than human only. It points to trees, rivers or animals as witnesses. Certain ethnic groups may be long gone, having left no artifacts, but trees and rivers may remember their presence and their songs. The closing paragraph of the novel seems to be the epitome of this theoretical concept.

There is no record of the lyrics of these [Beothuk] songs or the music to which the words were set. What remains of them is the property of brooks and ponds and marshes, of caribou and fox moving through the interior as they were sung two hundred years ago. Of each black spruce and fir offering its single note to the air where not a soul is left to hear it. (Crummey, 370)

To conclude, River Thieves is a compassionate novel that succeeds in telling the story of the Red Indians' extinction without appropriating it. The author bases his novel on scarce historical accounts of the described events and tries to imagine the actual motives that drove the settlers involved in the events. He consciously refuses to even fathom what colonization must have been like for the Beothuk or show their perspective from the first person narrative. In one of the interviews he explicates this in the following words: 
I'm dealing with the historical reality of the extinction of an entire race of people, the Beothuk. ... I was hoping the novel would give some sense of the enormity of that loss... . But I felt it would be wrong to write a novel about the Beothuk - to write as if we know more about them than we do, or to try to give them a voice that is absent from the historical record. Their absence, to my mind, is the point. The Beothuk are a shadowy presence in River Thieves, just as they are in what we know of the past....

In the end, River Thieves is a book about regret. For the individual characters, it's usually regret of a personal nature. For me, and hopefully for a reader, it goes somewhere beyond that, encompasses something larger. (Quoted in Chafe, 97)

The novel indisputably leaves the reader with the sense of loss and mourning, but simultaneously, in an amber-like manner, it preserves the existence of the Red Indians and commemorates their status as the first inhabitants of Newfoundland. Unearthing a dramatic past, the novel preserves the future memory of the Beothuk and saves it from sinking into oblivion. As Chafe observes, "[t] he Beothuk of River Thieves function more as an absence than a presence and are thus inseparable from the notion of loss that has become a fundamental part of Newfoundland's culture" (96). Nevertheless, rather than historical fiction, River Thieves is above all a story about the human condition per se. Weaving an intricate web of human relations and interdependencies, Crummey manages to restore agency to those who are situated on the periphery either due to gender, status or origin, thus reminding the reader that we are all capable of changing the course of history.

\section{References:}

Chafe, Paul. 2004. "Lament for a Notion: Loss and the Beothuk in Michael Crummey's River Thieves." Essays on Canadian Writing 82 (Spring), 93-117.

Crummey, Michael. 2003. The River Thieves. Edinburgh: Canongate.

Crummey, Michael. 2012. "Our symbiotic relationship with the stories that we tell." An Interview by Cynthia Sugars. Canadian Literature 212 (Spring), 105-119. 28 Feb. 2016. prima.uwb.edu. pl:2124/ehost/detail/detail?vid=4\&sid=d1f349d2-d303-4e19-9fa8-1231eea21261\%40sessionmgr101 \&hid=124\&bdata=Jmxhbmc9cGwmc2l0ZT1laG9zdC1saXZl\#AN=78296008\& db=a9h

Crummey, Michael. 2014. "Author Michael Crummey brings his own life into tale of smalltown Newfoundland." Interview by Eric Volmers. Calgary Herald 25 Aug. 2014. 28 Feb. 2016. www.calgaryherald.com/news/Author+Michael+Crummey+brings+life+into+tale + small + town +Newfoundland/10141933/story.html

Domańska, Ewa. 2014. "Historia ratownicza." Teksty Drugie 5, 12-26.

Foucault, Michel. 2003. Society Must Be Defended. Lectures at the College de France, 1975-76. Ed. Mauro Bertani and Alessandro Fontana. Trans. David Macey. New York: Picador.

hooks, bell. 1990. Yearning: Race, Gender and Cultural Politics. Boston, MA: South End Press. Sugars, Cynthia. 2005. “Original Sin, or, The Last of the First Ancestors: Michael Crummey's River Thieves." English Studies in Canada 31.4 (Dec.), 147-175.

White, Kenneth. 1992. “Elements of Geopoetics.” Edinburgh Review 88, 163-178. 